
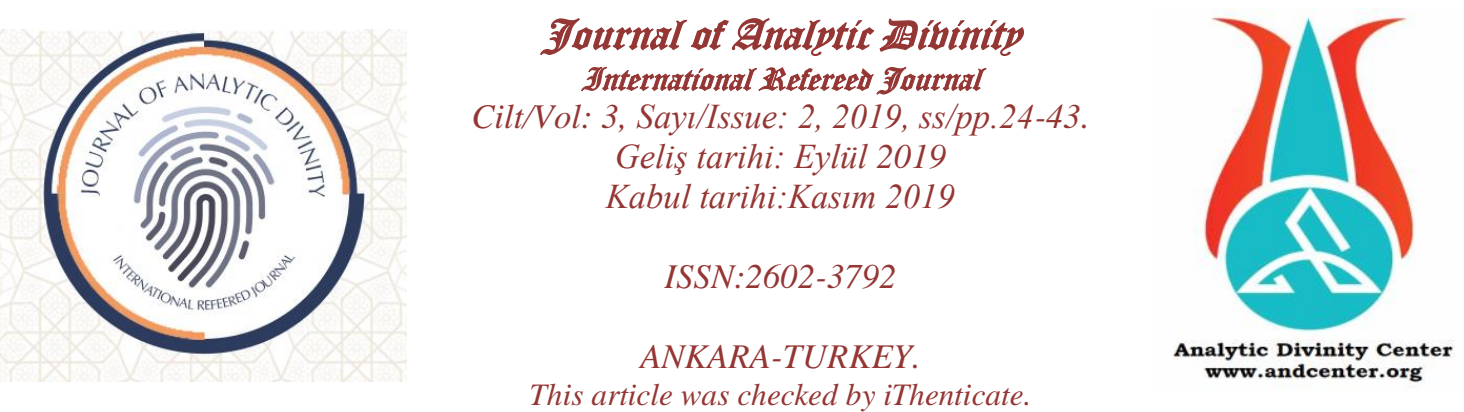

\title{
H. 25 SSABAN 1189 / M. 21 EKİM 1775 TARİHLİ MİHMANDAR MASRAF DEFTERİ ÜZERINE BİR DEĞERLENDİRME
}

\author{
Mustafa CAN *
}

\begin{abstract}
ÖZET
Devletlerarası ilişkilerde hükümdar, hanedan mensubu, elçi gibi resmi sıfatlı yabancı misafirlerin ağırlanması hususuna mihmandarlar nezaret ederdi. Geçmişi oldukça eski dönemlere giden mihmandarlık geleneği, Osmanlı Devleti tarafından da Türk-İslam gelenekleri çerçevesinde uygulanmıştır. Osmanlı mihmandarları, ülkeye gelen yabanc1 misafirlerin rahatını temin etmekle yükümlüydüler. Bu bağlamda Osmanlı diplomasi anlayışı gereği, elçi gibi resmi sıfatlı yabancı misafirlerin devlet tarafindan karşılanan zaruri harcamalarına da mihmandarlar nezaret ederdi. Mihmandarlar, hesap verilebilirlik adına, yaptıkları bu harcamaları en ince ayrıntısına kadar kayıt altına alırlardı. $\mathrm{Bu}$ şekilde tutulan kayitlardan birisi de İran elçisi Abdullah Bey’in mihmandarlığını yapmış olan Ali Ağa tarafından tutulan masraf defteridir. H. 25 Şaban 1189 / M. 21 Ekim 1775 tarihli bu defter, Osmanlı mihmandar geleneği hakkında önemli bilgiler içermektedir.
\end{abstract}

Anahtar Kelimeler: Osmanlı Devleti, Mihmandar, Elçi, Masraf.

\footnotetext{
* Arş. Gör. Dr.. Gazi Üniversitesi, Tarih Eğitimi Anabilim Dalı, eposta: mustafacan@gazi.edu.tr (C) Orcid: 0000-0002-6458-5007
} 


\title{
AN EVALUATION ON THE MIHMANDAR COST BOOK OF H. 25 ŞABAN 1189 / AD. OCTOBER 1775
}

\begin{abstract}
In interstate relations, the reception of official foreign guests such as sovereigns, dynasties, envoys was overseen by mihmandars. The mihmandar tradition, history of which goes back to ancient times, was applied by the Ottoman Empire within the framework of Turkish-Islamic traditions. The Ottoman mihmandars were obliged to ensure the comfort of foreign guests arriving in the country. In this context, the obligatory expenses of official guests such as envoys covered by Empire were supervised by the mihmandars. Mihmandars, for accountability, would record their expenses to the finest detail. One of the records kept in this way is the book of expenses which was kept by Ali Ağa, who was mihmandar of the Iranian ambassador Abdullah Bey. This book, dated H. 25 Şaban 1189 / AD. 25 October 1775, contains important information about the Ottoman mihmandar tradition.
\end{abstract} Cost.

Keywords: Ottoman State, Mihmandar, Envoy / Ambassador, 


\section{GİRIŞ̧}

Mihmandar, misafir karşılayan ve ağırlayan kimse anlamına gelmekte olup mihmandarların görev ve sorumlulukları da bu anlama uygun olarak şekillenmiştir. Bu bağlamda ülke topraklarına gelen yabancı devletlerin hükümdarlarına, ileri gelenlerine, elçilerine ve bunlarla gelen kişilere hizmet etmek için maiyetlerine atanan görevli memurlara mihmandar adı verilmiştir. Mihmandarlar bu tür misafirlerin yanlarında bulunup, onlara gerekli izahatlarda bulunarak kolaylik sağlamakla görevlendirilmişler; yerine getirmekle yükümlü oldukları mihmandarlık görevi ise mihmandarî olarak adlandırılmıştır (Şemseddin Sami, 1317: 1468, Pakalın, 1983: 533; Bozkurt, 2005: 25; Devellioğlu, 2008: 645). Geçmişi oldukça eski dönemlere giden mihmandarlık geleneği, devletlerarası ilişkiler ve elçi kabulleri ile bağlantılı olması nedeniyle farklı coğrafyalarda, farklı kültürlere sahip devletler tarafindan uygulanmiştır (Nicolson, 2001: 18-19). Osmanli Devleti'nde uygulanan mihmandar geleneği ise esas itibariyle Türk ve İslam kültüründe görülen uygulamalara dayanmaktadır. Bu bağlamda yabancı devletlerden Osmanlı topraklarına gelmiş olan itibar sahibi resmi sifatlı misafirlerin maiyetine tayin edilen görevlilere mihmandar adı verildiği görülmektedir. $\mathrm{Bu}$ husus ilgili kişilerin Osmanlı topraklarına ayak bastıkları andan, ülkeden ayrıldıkları zamana kadar misafir olarak kabul edildiklerini göstermektedir (Uzunçarş111, 1988: 276-277).

Osmanlı Devleti'nde mihmandarlık kadrolu bir devlet görevi değildi, bu nedenle mihmandarlar ihtiyaç halinde ve bu işi üstesinden gelebilecek kabiliyet ve donanıma sahip devlet görevlileri arasından tayin edilirdi (Bozkurt, 2005: 25). Seçilecek mihmandar özellikleri aslında maiyetine tayin edileceği misafirin özelliklerine göre değişmekte olup, misafire göre mihmandar tayin edilmekteydi. Gelecek olan misafirin özelliklerine göre seyfiye, ilmiye ya da kalemiyeden bir görevli mihmandar olarak tayin edilebilirdi. Mihmandarlik hizmeti genellikle saray mensuplarına çoğunlukla da kapıcıbaşı1 veya çavuşbaşılardan birisi tayin edilirdi. ${ }^{2}$ Eğer gelen misafir bir elçi ise mihmandar tayin edilen kişinin rütbesinin, elçinin rütbesine denk olmasina özellikle dikkat edilmekteydi (Kütükoğlu, 1989: 199).

Osmanlı Devleti'nde mihmandarlık görevi üç ayrı safhadan oluşmaktayd1. Bunlardan birincisi mihmandarların hizmetine atandıkları misafiri sınırda karşılayıp İstanbul'a kadar getirmelerine kadar olan süreci kapsamaktayd1. İkinci safha ise misafirin İstanbul'da

\footnotetext{
${ }_{1}$ Mesela H. Ramazan 1153 / M. Kasım/Aralık 1740 tarihinde gelen Rus elçisine de Dergâh-1 Âli kapıcıbaşılarından Ali mihmandar olarak tayin edilmişti (BOA. C.HR. 94/4667).

2 Örneğin H. 2 Rebiülahir 1054 / M. 8 Haziran 1644 tarihinde ülkesine dönmekte olan İran elçisine Divan-1 hümayun çavuşbaşılarından Derviş Mehmed mihmandar olarak tayin edilmişti (BOA. C. HR.92/4577).

31775 yılında İstanbul'a gelen Rus elçisi Repnin gibi bazı elçiler, mihmandar tayinine özel hassasiyet göstermekteydiler. Nitekim Repnin de 1740'da gelmiş olan Rus elçisine yapıldığı gibi gibi kendisine de mutlaka iki tuğlu bir vezirin mihmandar tayin edilmesi hususunda israr etmişti. (Kütükoğlu, 1989: 199).
} 
kaldığı zaman dilimindeki hizmeti içermekteydi. Üçüncü safha ise misafirin ülkesine dönmek için İstanbul'dan ayrılıp Osmanlı sınırlarından çıkmasına kadar olan süreçti. Misafirlerin hizmetleri için aynı anda yalnızca bir mihmandar tayin edilirdi. Bu safhalarin her birisinde misafirlere tayin edilen mihmandarlar değişebilirdi. Misafirlerin sınırdan karşılayıp İstanbul'a getirilmesi işini kapsayan mihmandarlığın ilk safhasında, mihmandarlara görevleri esnasında sıkıntı yaşamamaları adına divan-1 hümayundan yol hükmü ile yol güzergâhlarında gerekli olan binek hayvanlarını temin edebilmeleri için menzil ahkâmı verilirdi (BOA. AE. SABH. I. 297/19975). Mihmandarların geçilen yol güzergâhındaki yerel yöneticilerle iletişim halinde olması gerekirdi. Bunun nedeni herhangi bir kazaya mahal vermemek, koruma ve güvenlik konularında sorun yaşamamaktı (Topaktaş, 2014: 50). Bu koordinasyonun sağlanabilmesi adına Osmanlı topraklarına gelecek olan yabancı devlet adamı ve elçi gibi misafirlerin ne zaman gelecekleri, bunlar için kimin mihmandar tayin edildiği gibi hususlar, divandan gönderilen hükümlerle yol güzergâhındaki kadı, naib, ayan, mütesellim, voyvoda, yeniçeri serdarları ve vilayet iş erleri gibi yerel yöneticilere özel olarak bildirilirdi (BOA. AE. SMST. III. 3/134; BOA. C.HR.102/5066). Bu hükümlerde yerel yöneticilere, misafirlere yolculukları esnasinda herhangi bir sıkıntı çektirilmemesi özel olarak tembih edilirdi (BOA. C.HR. 57/2847).

Mihmandarların en temel görevi, misafirlerin rahatlık ve güvenliğini sağlamaktı. Bu hususta mihmandarlara gerekli kolaylık sağlanır ve misafirlerin yol masraflarına harcanmak üzere yeterli miktarda para avans olarak verilirdi. Yolculuk esnasında ihtiyaç duyulan g1da maddeleri, hayvan yemi, konaklama bedelleri, aydınlatma gideri, hamam ücreti gibi zaruri harcamalar, mihmandarlar tarafindan bu parayla gerçekleştirilirdi. Yapılan harcamaların defteri tutulur ve düzenlenen masraf defterlerine göre defterdarlıkça verilmiş olan avansın hesab1 görülürdü (Turan, 1964: 273-274). Mihmandarlar, önceden verilen bu paranın harcamalara yetmemesi durumunda ek para talebinde bulunabilirlerdi (BOA. AE. SSLM. III. 40/2327).

Mihmandarlara görevlerini ifa etmek için gerekli olan para merkezi hazineden tahsis edilebildiği gibi gerektiğinde yerel idareciler vasıtasıyla ahaliden tedarik edilen ayni ve nakdi tahsisatlar da hizmetlerine verilebilirdi. Misafir heyetlerinin yolculuk güzergâhında bulunan ahaliden toplanan bu ayni veya nakdi tahsisat, hükümet tarafindan onların mükellef oldukları vergilere mahsup edilirdi. ${ }^{4} \mathrm{Bu}$ nedenle

\footnotetext{
4 “Ma'rûz-ı dâi-i devletleri budur ki İran şâhı tarafindan Osmanlı Devleti'ne gönderilen elçi Hacı Han'a mihmandar tayin olunan dergâh-ı âli kapıcıbaşılarından Derviş Mehmet Ağa Haleb Eyaleti'nde nüzûl itdikleri mahâlde iktizâ iden zehâir tarâf-ı Devlet-i Âliyyeden gelen ber-muceb-i sûret defter ve
} 
mihmandarlara, yerel yöneticilere yönelik yazılmış olan bir ferman verilerek kendileriyle beraberlerinde gönderilirdi. Ayrıca yerel yöneticiler de bu fermanın içeriğini sicill-i mahfuza kaydetmek zorundaydılar (BOA. C. HR. 57/2847; BOA. C. HR. 20/997). Yapilan bütün harcamaların belgelendirilmesi ve halktan toplanan zahire ve paralarin bu kayıtlara göre toplanması gerekmekteydi (BOA. C. HR. 100/4969). Bu şekilde toplanan vergiler kadi huzurunda resmi olarak kaydedildikten sonra mihmandara teslim edilirdi (BOA. AE. SMST. II. 9/832.; BOA. C. HR. 20/997).

Beraberinde elçi ve maiyeti bulunan mihmandarlar, İstanbul'a birkaç günlük bir mesafeye geldiklerinde mektupla haber gönderirler; böylece İstanbul'da elçiyi karşılamak için gerekli hazırlıklar yapılırd1. ${ }^{5}$ Gerçekleştirilen karşılama merasiminden sonra elçi, mihmandarı ile alay eşliğinde ikamet edeceği konağa götürülürdü. Alay, elçinin konağına yakın bir yere gelindiğinde dağılır; elçiye konağına kadar yalnızca mihmandarı, on kadar divan çavuşu ve divan tercümanı refakat ederdi (BOA. BEO. A.TŞF. 359/194).

Mihmandarın görevi misafirleri İstanbul'a getirmekle bitmez, misafirler Osmanlı topraklarında bulundukları sürece ihtiyaçlarıyla ilgilenirlerdi (Uzunçarş1lı, 1988: 277). İstanbul'a gelindiğinde mihmandarlık hizmetinin ikinci safhası başlamış olurdu. Yöneticiler tarafından uygun görülmesi durumunda misafiri sinırdan itibaren karş1layıp İstanbul'a kadar getiren mihmandar, görevine İstanbul'da da devam ederdi (BOA. C. HR. 5/233).

Osmanlı Devleti'nde resmi sıfatlı misafirlere özellikle de elçilere mihmandar tayin edilmesi, Osmanlı diplomasi anlayışı ve devlet geleneklerinden kaynaklanmıştır. Bu çerçevede onlara sadece mihmandar tayin edilmemiş, Avrupa tarzı sürekli diplomasiye geçilene kadar olan süreçte Osmanlı topraklarındaki zaruri ihtiyaçları da devlet eliyle karşılanmıştır. Diplomatik misafirlere özellikle de elçilere yolculukları esnasinda harcirah ya da yol baha adiyla yapilan bu tahsisatlar, İstanbul'a gelindiğinde sona ermez hatta çeşitlenerek devam ederdi. Tayinat usulü olarak anilabilecek olan bu uygulamada nafaka baha, (BOA. İE. HR. 7/689) nan-baha gibi farkl1 isimler altında tahsis

\footnotetext{
ruznâmçe üzre olan zehâir hazır ve âmade olmak üzre Haleb Valisi tarâfından sâdır olan buyuruldu mümâileyh kulları yediyle kasaba-i Azaz'a imtisâli lede'l-akl meclis idüb ba'de's-sicil feth ve kiraât ve cümleye ilân oldukda bacem'ühüm semi'nâ ve ata'nâ didiklerinde daha önce Vali Ahmed Paşa tarafindan buyruldu geldikde bir mikdâr şa'îr kusurumuz olub onun dahi nüzûl vaktine dek tekmil ve nüzûlü ne mahâlle vâki' olur ise hâbir olduğumuz fenniyle aceleten ol mahâlle irsâl olunmak üzre her birleri taahhüd itmegin evvel ki vâki'-i hâldir der-devlet-i âliyyelerine ilâm olundu... 13 R 1153 (8 Temmuz 1740)" (BOA. AE. SMHD. I. 103/7280).

5 "Bu def'â gelecek Rusya Orta ilçisinin mihmândârn Ali Ağa kullarının gönderdiği menâzil defteridir. Yevm-i pazar günü Kırk Kilisa'ya yevm-i pazarirtesi Birgos'a yevm-i salı Karışdran'a yevm-i cehârşenbe Çorlu'ya yevm-i pençşenbe Silivri'ye yevm-i cuma Büyükçekmece'ye yevm-i cumairtesi Ayastefanoz'a nüzûl olunacağı mâlûm-ı devletleri buyuruldukda veliyü'n-niâm efendimin hüsn-i himmet-i âliyyeleri üzerimizde sâyebân buyurmaları niyâz-ı kullarıdır fi 23 ZA sene 176” (BOA. AE. SMST. III. 264/21169).
} 
edilen ödenekler genel olarak tayinat baha olarak anılird1 (Can, 2019: 216). Tayinat usulü ile ihtiyaçları karş1lanan misafirlerin İstanbul'da kaldıkları süre içerisinde ikamet edecekleri konakların kiraları ödenir, ayrıca mefruşatı da gerçekleştirilirdi. Misafirlerin ikamet edecekleri konaklarının döşenmesine de mihmandar nezaret eder ve bu iş için gerekli malzemeler mehterhâne-i amire ve matbah-1 âmire gibi yerlerden temin edilirdi. Konak döşemesi için gerekli malzemelerin buralarda bulunmaması durumlarında mirî akçe ile yenilerinin alınması da yine mihmandar nezaretinde gerçekleştirilirdi (BOA. C. HR. 5/233).

\section{Defteri}

25 Şaban 1189 / M. 21 Ekim 1775 Tarihli Mihmandar Masraf

Misafirlerin İstanbul'daki giderleri için gerekli olan para, mihmandarlara avans olarak verilebildiği gibi harcamalarından sonra da verilebilirdi. Mihmandarlar, misafirler için gerek yolculuk esnasında gerekse İstanbul'da yaptıkları harcamaları en ince ayrıntısına kadar kaydederek defterini tutarlard1. Mihmandar masraf defteri olarak tanımlanabilecek bu defterlerin tutulmas1, hazineden verilen avansin hesabının görülebilmesi için bir zorunluluktu. Bu şekilde tutulmuş mihmandar masraf defterlerinden birisi de İran elçisi Abdullah Bey'e, İstanbul'da kaldığı süre içerisinde mihmandarı Ali Ağa eliyle yapılan masrafları içeren 25 Şaban 1189 / M. 21 Ekim 1775 tarihli defterdir. Bu defterde de İran hükümdarı Zend Kerim Han tarafından gönderilen elçi Abdullah Bey ve maiyeti için yapılan harcamaların en ince ayrıntısına kadar tutulduğu görülmektedir.

İran'da Şia mezhebinin İmamiye koluna tabi Kürt kökenli Zend aşiretine mensup olan Kerim Han, Nadir Şah zamanında onun hizmetine alınmış ve Nadir Şah'ın kardeşinin oğlu Adil Şah'a hizmetinde bulunmuştur. Kerim Han H. 1165 / M. 1752 tarihinde İran'daki karışıklıktan istifade ederek rakiplerini mağlup etmiş ve H. 1173 / $\mathrm{M}$. 1759'da Fars; Irak-1 Acem taraflarını idaresi altına alarak Esterabad, Azerbaycan ve Horasan tarafları dişında İran'ın diğer bölgelerini hâkimiyeti altına almıştır. Zend Kerim Han'ın hükümdarlığı Osmanlılar tarafından da tasdik edilmiş ve I. Abdülhamid'in tahta çıkışını bildirmek amacıyla Sünbülzâde Vehbi Efendi name-i hümayun ile elçi olarak gönderilmiştir. Fakat İran sınırındaki Baban mutasarrıflığı nedeniyle iki taraf arasındaki ilişkiler bu şekilde devam etmeyip bozulmuş, hatta savaşa kadar gitmiştir. Osmanlı toprağı olan Basra yakınlarına askeri kuvvet gönderen Zend Kerim Han, bu hareketine karşın İstanbul'un tepkisini engellemek ve Osmanlı hükümetini yanıltmak amacıyla, askeri kuvvetlerin Maskat imamı ile savaşmak için sevk edildiğini beyan etmek 
üzere Abdullah isimli elçisini İstanbul'a göndermiştir (Mustafa Nuri Paşa, 1992: 169; Danişmend, 1972: 59; Uzunçarş111, 1995: 457-460).

İnceleme konusu olan defter, Zend Kerim Han tarafindan bu amaçla gönderilen Elçi Abdullah Bey'e İstanbul'da kaldığı süre içerisinde, mihmandarı Ali Ağa eliyle yapılan masrafların dökümünü içermektedir. $\mathrm{Bu}$ noktadan hareket edildiğinde Osmanlı Devleti ile Zend Kerim Han arasındaki olumsuz sürecin elçinin masraflarının karşılanmasına engel olmadığ1 anlaşılmaktadır. Zaten Osmanlı devlet geleneğinde uygulanan tayinat usulünde, temsil ettikleri devlet ile herhangi bir savaş halinde bile elçi tayinatlarının ödendiği sıkça karşılaşılan bir durumdur. ${ }^{6}$

Elçi Abdullah Bey'in İstanbul'daki masrafları için mihmandarı Ali Ağa'ya 1.000 kuruş avans verilmiştir. Yukarıda da belirtildiği üzere Ali Ağa yaptığı harcamaları kalem kalem kaydetmiş ve görevi sonunda divana arz etmiştir. İnceleme konusu olan bu defterin değerlendirilmesine geçmeden önce defterdeki masraf dökümünü verilmesi yerinde olacaktır. Defterdeki masrafların dökümü genel itibariyle aşağıdaki gibidir (BOA. C. HR. 184/9154):

\begin{tabular}{|l|l|}
\hline Harcamanın Cinsi & Miktar1 \\
\hline Kahveciye verilen araba bahası & 0120 \\
\hline İbrikdara verilen gargariye bahası & 0100 \\
\hline Makrameciye verilen kayı ücreti & 0080 \\
\hline İskemle ve ferraş & 0080 \\
\hline Desti ibrik ve bardak & 0120 \\
\hline Kestane, kavun ve karpuz ve üzüm & 0500 \\
\hline Ücret-i bargir ve yorganı kalfalarına verilen & 0400 \\
\hline Esb için çul ve torba ve gübre ve kaşağ1 ve kösdek & 0600 \\
ve payubend ve hammaliye & \\
\hline Def'a bargir ücreti & 0060 \\
\hline Üzüm ve kavun ve karpuz & 0500 \\
\hline Beğ efendimize hamam harçlı̆̆1 & 0400 \\
\hline Def'a Beğ efendimize nargile şişesi & 0840 \\
\hline Hindi tavuğu bahası & 0120 \\
\hline Kahveci ve peşkirci ve sofracıya futa 3 aded & 0600 \\
\hline Üzüm ve kavun ve karpuz & 0340 \\
\hline Balık ve ibrik ve bardak ve kandil ve hammaliye & 4520 \\
\hline Nakliye ve su küpü ma' kapak & 0100 \\
\hline Yağ temini & 0160 \\
\hline Yelpaze ve sineklik ve hammaliye & 0240 \\
\hline Mehterlere ve aşçılara ve akkâmlara peştemal & 0230 \\
\hline
\end{tabular}

${ }^{6} \mathrm{Bu}$ bağlamda elçilerin refahını sağlamak büyük hükümdarların görevi olduğu gerekçesiyle, 1551 yılında hapsedilen Avusturya elçisinin günlük tayinatı 5 akçeden 15 akçeye yükseltilmişti (Gürkan, 2015: 384). Benzer şekilde 1787-1792 Osmanl1-Rus savaş1 esnasında Yedikule'ye hapsedilen Bulgakov'un günlük 12 kuruş olan tayinatı da 25 kuruşa çıkartılmıştı (Topaktaş, 2015: 38). 
Journal of Analytic Divinity Cilt/Vol:3, Sayl/Issue: 2, 2019, ss/pp.24-43.

\begin{tabular}{|c|c|}
\hline Astar top 10 aded & 5470 \\
\hline Kahve dökmesine & 0040 \\
\hline Aşç1lara verilen & 0120 \\
\hline Ayva emrud & 0080 \\
\hline Misk sabunu & 0240 \\
\hline Yekûn & 6410 \\
\hline Tarçın ve karanfil ve kırmız & 0260 \\
\hline Öd ve anber & 0500 \\
\hline Kahve futasi & 0060 \\
\hline Def'a kırmız ve za'feran ve karanfil & 0400 \\
\hline Reçel bahası & 0460 \\
\hline Yekûn & 8090 \\
\hline Zeytun bahası & 0100 \\
\hline Penayir-i kaşkaval & 0140 \\
\hline Üzüm ve kavun ve karpuz & 0340 \\
\hline Çiçek suyu & 0060 \\
\hline Gül suyu ve limon suyu & 0100 \\
\hline Yekûn & 8830 \\
\hline Badem bahas1 & 0160 \\
\hline Kilariyeye verilen gül şerbeti & 0300 \\
\hline Macun ağasına macun & 0240 \\
\hline Ücret-i bargir ve toprak şamdan ve ibrik & 0060 \\
\hline Körük ve yelpaze ve çömlek ve sünger baha & 0080 \\
\hline Yekûn & 9670 \\
\hline Yoğurd ve üzüm ve nan-1 aziz & 0060 \\
\hline Sak1z ve elma ve emrud ve limon ve ücret-i dabbe & 0150 \\
\hline Ve hanciya verilen baha-yı lüle & 0065 \\
\hline Börek ve simid ve koğa baha & 0110 \\
\hline Kahve dökmesine & 0040 \\
\hline Yekûn & 10095 \\
\hline Yoğurd ve limon ve sarımsak ve findık ve koruk & 0060 \\
\hline Badem ve elek ve aşçılara süpürge & 0090 \\
\hline Zahire ve hatab hamaliyeleri & 0120 \\
\hline Revgan fiç1s1 ve sünbül & 0140 \\
\hline Üzüm ve kavun ve karpuz baha & 0340 \\
\hline Yekûn & 10845 \\
\hline Kaş1k ve iskemle ve ferraş ve süpürge & 00130 \\
\hline Nan-1 aziz-i has & 00400 \\
\hline Limon ve çiçek ve gül suları bahası & 00160 \\
\hline Elma ve armud & 00060 \\
\hline Keşkeklik hinta & 00100 \\
\hline
\end{tabular}




\begin{tabular}{|c|c|}
\hline Yekûn & 11695 \\
\hline Seped ve sarımsak ve hammaliye & 00075 \\
\hline Sim ibrik tamiri & 00040 \\
\hline Misk sabunu & 00060 \\
\hline Simit yoğurd turşu ve üzüm ve çubuk teli bahası & 00080 \\
\hline Badıncan ve tavuk ve desti ve turşu ma' hamaliye & 12090 \\
\hline Hoşab kasesi ve reçel tabağı ve soğan tabağ & 00600 \\
\hline Kömür hammaliyesi ve hatab ve turşu ve sarımsak & 00120 \\
\hline Simit ve turşu & 00060 \\
\hline Kahve dökmesi & 00040 \\
\hline Eşrübe & 00400 \\
\hline Yekûn & 12910 \\
\hline Hanciya lüle baha & 00040 \\
\hline Asçılara hasır & 00060 \\
\hline Def'a turşu ve Sarımsak ve fındık & 00040 \\
\hline Peynir baha & 00138 \\
\hline Üzüm ve kavun ve karpuz & 00340 \\
\hline Yekûn & 13528 \\
\hline Ve hanciya mankır baha & 00040 \\
\hline Asel baha & 00340 \\
\hline Misk sabunu & 00120 \\
\hline Fincan ve kaş1k & 00160 \\
\hline Limon ve mezbele ihrac1 ve desti hammaliyesi & 01100 \\
\hline Yekûn & 15288 \\
\hline Tabla iki aded & 00110 \\
\hline Kayık için kömür ve hatab hammaliyeleri & 00060 \\
\hline Kahve dökmesi & 00040 \\
\hline Șair ve saman hammaliyeleri & 00168 \\
\hline Nan-1 aziz-i has & 00440 \\
\hline Yekûn & 16196 \\
\hline Üzüm ve dakik ve ma' hammaliye & 00090 \\
\hline Revgan-1 sade & 01000 \\
\hline Limon suyu ve çiçek suyu ve gül suyu & 00220 \\
\hline Kilarciya verilen harç baha & 00800 \\
\hline Tavuk hammaliyesi & 00015 \\
\hline Yekûn & 18221 \\
\hline Kayıkçlara inamat & 00440 \\
\hline Hatab ve kömür hammaliyesi & 00120 \\
\hline Çiçek suyu & 00060 \\
\hline İbrikdara misk sabunu baha & 00120 \\
\hline Asdar baha & 00200 \\
\hline Yekûn & 19161 \\
\hline Revgan-1 zeyt hammaliyesi ve limon & 00060 \\
\hline Kırmız ve revgan destisi ve mısır tavuğu & 00220 \\
\hline
\end{tabular}




\begin{tabular}{|c|c|}
\hline Öd ve anber & 00460 \\
\hline Esb nallatmasina & 00090 \\
\hline Misk sabunu & 00120 \\
\hline Yekûn & 20111 \\
\hline Kahve dökmesi & 00040 \\
\hline Kilarcıya masarıfat içün verilen & 00800 \\
\hline Ücret-i bargir & 00070 \\
\hline Duhanciya lüle baha & 00040 \\
\hline Şamdan ve ibrik ve süpürge & 00110 \\
\hline Yekûn & 21171 \\
\hline Şair ve saman ve kömür ve hatab hammaliyesi & 00120 \\
\hline Üzüm ve kavun ve karpuz baha & 00360 \\
\hline Ücret-i bargir & 00060 \\
\hline Def'a hatab ve kömür hamaliyesi & 00060 \\
\hline Eşrübe & 00240 \\
\hline Yekûn & 22011 \\
\hline Tabh-1 börek ve baklava & 00400 \\
\hline Mezbele ihracı & 00120 \\
\hline Def'a ücret-i bargir & 00240 \\
\hline Kömür ve hatab baha ve hamaliyeleri & 00160 \\
\hline Kilarc1 masarıfat1 & 00800 \\
\hline Yekûn & 23731 \\
\hline Kahve dökmesi & 00040 \\
\hline Üzüm ve kavun ve karpuz & 00340 \\
\hline Kâğ1d deste baha & 00180 \\
\hline Paça ütülmesine & 00085 \\
\hline Su küpü ve nakliye & 00060 \\
\hline Yekûn & 24436 \\
\hline Bargir ücreti & 00060 \\
\hline Hatab ve kömür baha ve hamaliyesi & 00120 \\
\hline Üzüm ve kavun ve karpuz baha & 00340 \\
\hline Öd ve anber & 00420 \\
\hline Dakik-i has hamaliyesi & 00030 \\
\hline Yekûn & 25406 \\
\hline Yeniçerilere inam & 00220 \\
\hline Hatab hamaliyesi çiçek suyu ve gülsuyu & 00180 \\
\hline Süpürge ve lağımciya verilen & 00190 \\
\hline F1stık Ve soğan ve sarımsak & 00100 \\
\hline Kayıkç1lara verilen inamat & 00220 \\
\hline Yekûn & 26366 \\
\hline
\end{tabular}




\begin{tabular}{|c|c|}
\hline $\begin{array}{c}\text { Hatab ve kömür ve şair ve saman ve anbar } \\
\text { hammaliyeleri }\end{array}$ & 00210 \\
\hline Elma ve ayva ve emrud & 00140 \\
\hline Odalarda alınan desti ve ibrik ve bardak & 00040 \\
\hline $\begin{array}{l}\text { Çiçek suyu ve limon suyu ve ücret-i kayık ve pirinç } \\
\text { hamaliyesi }\end{array}$ & 00180 \\
\hline Misk sabunu & 00120 \\
\hline Badem kırmız ve tarçın ve karanfil & 00460 \\
\hline Hatab ve kömür hamaliyesi & 00120 \\
\hline Nan-1 aziz-i has & 00360 \\
\hline Kilarciya verilen masarıfat & 00700 \\
\hline Kahveciye körük ve maşa ve sacayağ 1 & 00080 \\
\hline Yekûn & 28766 \\
\hline Kahve dökmesine & 00040 \\
\hline Üzüm kavun ve karpuz & 00340 \\
\hline Eşrübe & 00220 \\
\hline Elma emrud ve ayva & 00140 \\
\hline Kırmız ve zaferan ve tarçın ve karanfil & 00550 \\
\hline Yekûn & 30016 \\
\hline Beg efendi içün arusek berber aynası yekpare & 00840 \\
\hline Balık ve misır tavuğu & 00240 \\
\hline Öd ve anber & 00420 \\
\hline Cedid Acem dibas1 yorgan baha 1 aded & 01800 \\
\hline Çarşab 2 aded & 00600 \\
\hline Yekûn & 33906 \\
\hline Yüz yasdığ1 mücessem & 00600 \\
\hline Koltuk yasdığ1 2 aded & 00440 \\
\hline Hammam harçlığ1 & 00300 \\
\hline Perde baha 12 aded & 00480 \\
\hline Def'a asdar top 5 aded & 00250 \\
\hline Yekûn & 35576 \\
\hline Misk sabunu & 00160 \\
\hline Kirmız tarçın ve karanfil & 00230 \\
\hline Üzüm ve kavun ve karpuz & 00340 \\
\hline Limon suyu ve çiçek suyu ve gülsuyu & 00260 \\
\hline Mezbele ihrac1 & 00110 \\
\hline Yekûn & 36636 \\
\hline Aşçılara aylık & 03600 \\
\hline Akkâmlara aylık & 00240 \\
\hline Sayise aylik & 00240 \\
\hline Kandil & 00060 \\
\hline Dolablara ve kapulara kilid & 00150 \\
\hline Yekûn & 40526 \\
\hline Balik & 00065 \\
\hline
\end{tabular}


Journal of Analytic Divinity Cilt/Vol:3, Sayr/Issue: 2, 2019, ss/pp.24-43.

\begin{tabular}{|l|r|}
\hline Kaymak & 00880 \\
\hline Öd ve anber & 00420 \\
\hline Eşrübe & 00420 \\
\hline Üzüm ve kavun ve karpuz & 00320 \\
\hline Yekûn & $\mathbf{4 2 6 3 1}$ \\
\hline Paça & 01320 \\
\hline Mumbar & 01150 \\
\hline Tömbaki & 03600 \\
\hline Sakaya verilen & 01810 \\
\hline Mezbele ihracı & 00120 \\
\hline Yekûn & $\mathbf{5 0 6 3 1}$ \\
\hline Çay şerbeti baha & 01680 \\
\hline Duhan baha & 01260 \\
\hline Kendünün yol nargilesi tamir & 00420 \\
\hline Soğan tabağ1 ve bardak & 00250 \\
\hline Kendilerine birer değirmi yemeni baha yekûnu & 00600 \\
\hline Yekûn & $\mathbf{5 4 8 4 1}$ \\
\hline Nakl-i yekun & 54841 \\
\hline Zuhurat-1 sebzevat & 01600 \\
\hline Zuhurat-1 nan-1 aziz-i müzdadiye & 00600 \\
\hline Fener baha & 00260 \\
\hline Matara baha & para \\
\hline Nakl-i Üsküdar hamaliye ve ücret-i kayık inamatı & $\mathbf{1 2}$ para \\
\hline Yekûn & $\mathbf{5 7 9 9 2}$ \\
\hline
\end{tabular}

Defterdeki giderler herhangi bir sinıflandırmaya tabi tutulmadan kaydedilmiş olup defterin tutuluş yöntemi ile ilgili herhangi bir kayda da rastlanmamaktadir. Bununla birlikte masrafların yirmi dokuz ara toplamda kaydedilmiş olması, harcamaların günlük olarak kaydedildiğini düşündürmektedir. Bu husus elçilerin İstanbul'da kalma süreleri ile de doğru orantılıdır. Yabancı elçilerin İstanbul'da geçirdikleri süre, mukim elçiler ve fevkalade elçiler için değişmekle birlikte mukim elçiler devletleri tarafından belirlenen süre boyunca İstanbul'da kalırlarken, fevkalade elçilerin İstanbul'da kalmaları gereken süre en az bir ayı bulmaktaydı. Bu bağlamda 1717'de gelen Hint elçisi Muhammed Niyaz Han, Topkap1 Sarayı'nda ilk olarak H. 25 Safer 1129 / M. 7 Şubat 1717 Pazar günü kabul edilmiş; dönüş için ikinci kere huzura kabulü ise H. 25 Rebülevvel 1129 / M. 9 Mart 1717 Salı günü gerçekleşmişti (BOA. BEO. A.TŞF. 
346/13). Nadir Şah'in elçisi Abdülkerim Bey ise ilk olarak H. 16 Rebiülevvel 1150 / M. 14 Temmuz 1737'de huzura kabul edilmiş, dönüşünde kendisine verilecek olan name-i hümayun ise $H$. 13 Rebiülahir 1150 / M. 11 Ağustos 1737'de teslim edilmişti (BOA. BEO. A.TŞF. 348/.4 a). Bu örnekler fevkalade elçilerin İstanbul'da ortalama bir ay kaldıklarını teyit etmektedir. Bu nedenle Zend Kerim Han'ın elçisi Abdullah Bey için tutulan masraf defterinin de gün gün yapılan harcamalara göre tutulduğu söylenebilir. Elçilere ülkelerine dönmek üzere iken verilen hediyelerin son kalemlerde kaydedilmesinin yanı sıra elçinin hizmetinde bulunan aşçı, akkâm, seyis gibi hizmetkârlara verilen ücretin aylik olarak zikredilmesi ve bunlara da son kalemlerde yer verilmesi bu hususu teyit etmektedir. Yine ilk kalemdeki harcamaların sonraki kalemlere nazaran daha çok ve çeşitli olması, elçinin konağına ilk yerleştiğinde eksiklerin daha çok olabileceğini düşündürmekte ve defterin gün gün tutulmuş olduğu düşüncesini doğrulayıcı bir özellik taşımaktadir.

İlgili masraf defterindeki harcamalar genel anlamda aşağıdaki şekilde kategorize edilebilir.

\section{Bahşişler}

Konak ve konaklama giderleri

G1da harcamaları

Temizlik giderleri

Ulaşım masrafları

Hizmet giderleri

- $\quad$ Elçinin şahsı için yapılan harcamalar ve verilen hediyeler Yan giderler

Defterde geçen kahveciye verilen araba bahası, ibrikdâra verilen gargariye bahası, makrameciye verilen kayık ücreti, hancıya mankır baha, kayıkçılara in'amat ve yeniçerilere in'am şeklindeki kayıtlardan, bu görevlilere verilen miktarların bahşiş olduğu anlaşılmaktadır. Bahşiş, Osmanlı elçilik faaliyetlerinde sıkça rastlanan bir husustur. Gidilen ülkelerde elçilik heyetine bahşiş verilmesi Osmanlı elçileri tarafından uygulanan bir gelenek olduğu gibi Osmanlı Devleti'ne gelen elçiler de kendilerine hizmet eden görevlilere avaid adı altında bahşişler vermek durumundaydilar. Mesela 1665 yılında Avusturya'ya gönderilen Elçi Kara Mehmed Paşa Viyana'daki konağına yerleştirildikten sonra kendisine meyve, şekerli macun, içecek, çarşaf ve yorgan gibi tefrişat malzemeleri getirilmiş paşa da bu hediyeleri getirenlere onar altın bahşiş vermişti (Evliya Çelebi, 1318: 247-248). M. 1721-1722 tarihinde İstanbul'a gelen İran elçisi Murtaza Kulu Han da Nakkaş Paşa Sarayına yerleştikten sonra teşrifati efendi'ye 70 , çavuşlar kâtibine 50 , çavuşlar eminine 50, çavuşlara, duacı çavuşa 10, kılavuz çavuşa 20, asesbaşına 20, subaşına 20, mehter çavuşlarına 10 , çavuşbaşının çukadarına 20, şatıra 5, elçiye tayin edilen çorbacıya 30, elçiye at getiren dört kişiye 20, 
elçiye tayin edilen 7 çavuşa 20 olmak üzere toplamda 495 kuruş avaid dağıtmıştı (BOA. BEO. A.TŞF. 347, s. 135).

Elçi konaklarının, kendileri İstanbul'da gelmeden önce mihmandar marifetiyle döşenip hazır hâle getirildiği yukarıda ifade edilmişti. İnceleme konusu defterde rastlanan kayıtlar, elçiler geldikten sonra da konaklama hususunda ortaya çıkan bir takım eksikliklerin yine mihmandar eliyle giderilmeye devam edildiğini göstermektedir. $\mathrm{Bu}$ bağlamda elçi için alınan Acem dibası yorgan, çarşaf, koltuk yastıklardan başka astar, perde, iskemle, körük, yelpaze, sineklik, kandil, dolap ve kapılara alınan kilit gibi malzemeler konak ve konaklama giderleri arasında sayılabilir. Yukarıda da belirtildiği üzere konak döşemesi için gerekli malzemelerin Mehterhane-i Âmire ve Matbah-1 Âmire'de bulunmaması durumunda mihmandar tarafından mirî akçe ile yenileri satın alınarak bu eksiklikler giderilirdi (BOA. AE. SSLM. III.217/12722). Mihmandar Ali Ağa da bu eksiklikleri aynı şekilde gidermişti. Ali Ağa'nın bu iş için yaptığı harcamaların ufak miktarlarda olması ise konağın önceden hazır hâle getirildiğini göstermektedir.

Defterde elçi için yapıldığı ifade edilen harcamaların önemli bir k1sminı g1da harcamaları meydana getirmektedir. Fakat burada dikkati çeken husus mihmandar eliyle yapılan harcamaların genel anlamda temel gıda maddelerini içermiyor olmasıdır. Bu durumun nedeni elçi ve maiyeti için verilen temel gida maddelerinin tayinat usulü uyarınca önceden tespit edilmesi ve ilgili birimlerce aynî olarak temin ediliyor olmasıdır. Bu şekilde tayinatların aynî olarak verileceği durumlarda et, kasapbaş1; kümes hayvanları, tavukçubaş1; arpa ve saman, arpa emini; diğer gıda maddeleri, Matbah-1 Âmire emini; odun ve kömür, İstanbul ağası; hayvan yemleri ise Istabl-1 Âmire tarafından temin edilirdi (Kütükoğlu, 1989: 216). Elçi Abdullah Bey için de durumun aynı şekilde olduğu, mihmandar Ali Ağa tarafından yapılan gida harcamalarından da anlaşılmaktadır. Ali Ağa marifetiyle alınan gida maddeleri genel itibariyle kavun, karpuz, elma, ayva, armut, üzüm gibi meyveler; limon, sarımsak vb. gibi sebzeler; kestane, fındık, fistık, vb. gibi kuruyemişler; tarçın, karanfil, safran gibi baharatlar; peynir, reçel, zeytin, yoğurt, turşu, balık, tavuk, kahve, eşrübe olarak kaydedilen diğer içecekler vb. gibi temel gida maddesi olarak tanımlanamayacak gida maddeleridir. Bunların dişında keşkeklik hınta (buğday) balık, kaymak, börek ve baklava gibi daha çok damak zevkine hitap eden yiyecekler için yapilan harcamalar da bu hususu teyit etmektedir. ${ }^{7}$ Ayrıca nân-ı aziz şeklindeki birkaç kayıttan,

\footnotetext{
7 Osmanlı Devleti gelen elçilerin damak zevklerine hitap eden ve temel ihtiyaç maddeleri içerine girmeyen malzemeler arasında alkollü içecekler de gösterilebilir. Her elçilik heyeti için farklı olarak hazırlanan tayinat listelerinde ekmek, et, pirinç, un, yağ, gibi temel gida maddelerinin değişmemekle birlikte Hristiyan elçilere alkollü içecekler (şarap, rakı vb.) temin edildiğine sıklıkla rastlanmaktadır.
} 
elçiye aynî olarak verilen ekmek gibi temel gida maddelerinde tahsis edilen miktarın aşılması durumunda, bu açığın da mihmandar eliyle kapatıldığı anlaşılmaktadır. Defterde yer alan zuhûrat-ı nân-ı aziz-i müzdâdiye kaydı da bu durumun göstergesidir.

Temizlik giderleri olarak sinıflandırabileceğimiz harcamalar içerisinde öncelikle elçi için verilen hamam harçlığı zikredilebilir. Elçiye İstanbul'da kaldığı süre içerisinde birisi ilk harcama kaleminde 400 akçe, diğeri sonraki günlerde 300 akçe olmak üzere iki defa da toplam 700 akçe hamam ücreti verilmiştir. Bunlardan 400 akçe olan ilkinin ilk kalemde belirtilmesi elçi ve maiyetinin yoldan gelmiş olmalarına dikkat edildiğini göstermektedir. Bunların dişında mezbele ihrâcı olarak ifade edilen ikametgâhtaki çöp tarzı atıkların çıkartılması da dört kere gerçekleştirilmiştir. Elçinin İstanbul'da kaldığı sürenin bir ay olduğu düşünüldügünde mezbele ihracinın ortalama hafta da bir kez gerçekleştirildiği düşünülebilir. Ayrıca lâğımcıya verilen ücrette yine temizlik amaçlı giderler arasında değerlendirilebilir. Süpürge, ferrâş, misk sabunu gibi malzemelere verilen ücretler de şüphesiz temizlik giderleri içerisinde olmakla birlikte öd ve anber gibi güzel kokular için ödenen miktarlar da bu grupta değerlendirilebilir.

Ulaşım harcamaları olarak tasnif edebileceğimiz kısımda ise elçi ve maiyetinin ulaşım hizmetleri için yapılan harcamalarla alınan malzemelerin tassıma giderleri yer almaktadır. Bu noktada son kalemdeki "nâkl-i Üsküdâr hammâliye ve ücret-i kayık in'amâtı" kaydının, elçilik heyetinin ülkelerine dönüşü esnasında heyettekileri ve ağırlıklarını Üsküdar'a geçiren kayık ve kayıkçılara verilen ücret olduğu anlaş1lmaktadır. Defterin muhtelif yerlerinde geçen "ücret-i kayık, ücret- $i$ bârgir" ve "nâkliye" gibi kayıtlarının da elçi ve maiyeti için gerekli ihtiyaç malzemelerinin taşıma ücreti olduğu anlassılmaktadır. Yine son kayıtlardaki "nâkl-i Üsküdâr hammâliye ve ücret-i kayık in'amâtı" ifadesinden sonra yer alan "fener" ve "matara" bahalarinın da yolculuk esnasında kullanıldığı düşünülebilir.

İnceleme konusu masraf defterindeki bir diğer harcama grubu ise hizmet giderleri olarak adlandirabilecek harcamalardır. Hizmet harcamaları içerisinde en çok karşılaşılan ödeme türü, konağa getirilen malzemeleri taşıyan hamallara verilen hamaliyelerdir. Bunlardan başka elçinin ikâmetgâhında hizmet eden aşçılar, deve ve katırlara bakan akkâmlar, at bakıcısı seyis ve su hizmetlerini gören sakaya verilen ücretler de hizmet giderleri grubuna girmektedir. Bu arada seyisin bir tane akkâmların ise birden fazla olması, elçilik heyeti için tahsis edilen atın sadece elçiye tahsis edilmek üzere bir tane olduğunu göstermektedir. Hizmet gurubu içerisinde akkâmların yer alması elçinin maiyeti için katır ve develerin kullanıldığını göstermektedir. Defterdeki "esb için çul ve torba ve gübre ve kaşağı ve kösdek ve pâyubend ve hammâliye" ile "esb

Mesela H. 1153 / M. 1740-1741 tarihinde gelen Rus elçisi Romançof'a verilen tayinat içerisinde de 500 kıyye şarap bulunmaktaydı (BOA. C. HR. 123/6101). 
nallatmasına" şeklindeki diğer iki kayıt da elçi ve maiyetine tahsis edilen atın bir tane olduğunu teyit etmektedir. Bu durum İran'dan gelen elçilerin maiyetlerine at tahsis edilmediği; bunun ancak elçi talebiyle gerçekleştirildiği (Can, 2019: 194) bilgisini de doğrulamaktadır. Böylece kayıtlardan Elçi Abdullah Bey'in maiyeti için at talep etmediği anlaş1lmaktadır. Yine elçinin talep ettiği yorganın mehterhanede mevcut olmadığı ve bu nedenle yenisinin yaptırıldığı da görülmektedir. Yorganın tanımı yapılırken "cedid Acem dibâsı yorgan" ifadesindeki cedid kelimesi de buna işaret etmektedir. Defterde "yorganı kalfalarına" şeklinde kaydedilen 400 akçe de elçinin şahsına alınan bu yorganın işçiliği için ödenen ayrı bir hizmet gideridir.

Mihmandar Ali Ağa'nın kayıt altına aldığı bir diğer harcama grubu da elçinin şahsı için yapılan harcamalar ve verilen hediyelerdir. Bu bağlamda elçiye bir cedid Acem dibası yorgan ve mücessem yüz yastı̆̆1, iki koltuk yastığı, iki çarşaf, nargile şişesi, yekpare arusek ${ }^{8}$ berber aynası, birer değirmi yemeni alınmış ve ayrıca yol nargilesi de tamir ettirilmiştir. Osmanlı Devleti'nde yabancı elçiler padişahın huzuruna hediyesiz çıkamadıkları gibi ülkelerine dönmeden önce kendilerine de çeşitli hediyeler verilmekteydi. Elçilere verilen bu hediyelerden başka ayrıca sadrazamla görüşmelerinde ve huzura kabullerinde de sembolik bir takım hediyeler takdim edilirdi. Makrame, yemeni ve yağlık gibi mendil tarzı kumaşlar bu şekilde onları onurlandırmak için kullanılan sembollerdendi (Can, 2019: 319). Defterden anlaşıldığına göre mihmandarlar da elçilere yemeni tarzı sembolik hediyeler takdim etmekteydiler. Mihmandar Ali Ağa tarafından kaydedilen yemeninin sadrazam veya basska bir devlet adamı adına kaydedilmemiş olması, Ali Ağa'nın bunu elçiye kendi adına vermiş olduğunu göstermektedir.

Elçi Abdullah Bey'e yapılan harcamalarda yukarıdaki kategorilerin dişında kalan ve ihtiyaca binaen gerçekleştirilip yan giderler olarak adlandirılabilecek kalemler de bulunmaktadir. Bu şekilde tutulan kayıtlar doğrudan elçi ve maiyeti için yapilan harcamalar değil de, hizmet için gerekli malzemelerin temini şeklindedir. Defterde geçen kahveci, peşkirci ve sofracıya alınan futalar, mehterlere, aşçılara ve akkâmlara alınan peştamallar, aşçılara alınan hasır, kahveciye alınan körük, maşa ve sacayağ1 gibi harcamalar bu şekilde gerçekleştirilen yan giderlerdir. Elçiye tahsis edilen at için çul, torba, gübre, kaşağı, köstek, payubend ve nallatma masrafi; sim ibrik tamiri; hancıya verilen lüle baha ve ayrıca alınan deste kâğıt ücreti de ihtiyaca binaen gerçekleştirilen yan ödemeler grubuna girmektedir.

Elçi Abdullah Bey’in harcamaları için mihmandarı Ali Ağa'ya avans olarak 1000 kuruş verildiği yukarıda ifade edilmişti. Defterdeki

8 Yeşil ve pembe dalgalı bir çeşit sedef (Şemseddin Sami, 1317: 934). 
kayıtlardan anlaşıldığına göre Ali Ağa'nın elçi ve maiyetinin hizmetine harcadığ1 para, kendisine verilen miktarı aşarak 1.449,5 kuruş tutmuştu. Durumu arzuhalle divana bildiren Ali Ağa'ya, fazladan harcamak zorunda kaldığ1 449,5 kuruştan 49,5 kuruşu düşülerek kalan 400 kuruşun verilmesi kararlaştırılmış ve bu karar H. 13 Safer 1190 / M. 3 Nisan 1776 tarihinde onaylanmıştır (BOA. C. HR. 184/9154).

\section{SONUC}

Geçmişi ilkçağlara kadar giden mihmandarlık, Osmanlı Devleti'nde de Türk ve İslam kültürlerindeki şekliyle uygulanmış bir gelenektir. Bu çerçevede Osmanlı topraklarına gelen hükümdar, hanedan mensubu, elçi vb. gibi resmi sıfatlı yabancı misafirlere, ülke içerisinde sıkıntı yaşamamaları adına mihmandar adı verilen görevliler tayin edilmiştir. Osmanlı mihmandarları, maiyetlerine tayin edildikleri misafirlerin rahat ve güvenliklerinin sağlanması, iaşelerinin temin edilmesi vb. gibi görevleri yerine getirmişlerdir. Bu bağlamda Osmanlı mihmandarlık geleneği, Osmanlı cömertliğinin de bir simgesi olmuştur. Osmanlı diplomasi geleneği gereği, resmi sıfatlı yabancı misafirler için mihmandar eliyle gerçekleştirilen harcamalar, yine mihmandarlar tarafından en ince ayrıntısına kadar kayıt altına alınmısstır. Bu şekilde tutulan kayıtlardan birisi olan 25 Şaban 1189 / M. 21 Ekim 1775 tarihli mihmandar masraf defteri, İran elçisi Abdullah Bey'e, İstanbul'da kaldığ1 süre içerisinde mihmandarı Ali Ağa eliyle yapılan masrafları içermektedir. Ali Ağa'nın tuttuğu kayıtlar, Osmanlı mihmandar geleneğinin inceliklerini gözler önüne sermekte, mihmandarların görev ve sorumlulukları hakkında güzel bir örnek teşkil etmektedir. İnceleme konusu defter, Osmanlı devlet geleneği içerisinde şimdiye kadar çoğunlukla gözden kaçmış olan mihmandar geleneğine, dolayısıyla Osmanlı diplomasi geleneğinin farklı yönlerine 1ş1k tutmaktadır.

\section{KAYNAKÇA}

Arşiv Kaynakları

T.C. Cumhurbaşkanlığı Devlet Arşivleri, Başkanlık Osmanlı

\section{Arşivi (BOA)}

BOA. AE. SABH. I. 297/19975

BOA. AE. SMHD. I. 103/7280; 9/832.;

BOA. AE. SMST. III. 264/21169; 3/134;

BOA. AE. SSLM. III. 217/12722; 40/2327.

BOA. BEO. A.TŞF. 346, 347, 348, 359.

BOA. C. HR. 5/233; 20/997; 57/2847; 92/4577; 94/4667;

$100 / 4969 ; 102 / 5066 ; 123 / 6101 ; 184 / 9154$.

BOA. İE. HR. 7/689.

\section{Telif Eserler}


Bozkurt, N. (2005). Mihmandar. DİA. C. 30, Ss. 25-26.

Can, M. (2019). Sultanin Kapisinda: Kudret-Heybet-Adalet (Osmanlı Devleti'nde Yabancı Elçiler). Ankara: Gazi Kitabevi.

Danişmend, İ. H. (1972). İzahlı Osmanlı Tarihi Kronolojisi 4 M. 17031924 (H.1115-1342). İstanbul: Türkiye Yayınevi.

Devellioğlu, F. (2008). Osmanlıca-Türkçe Ansiklopedik Lûgat. 25. Baskı. Ankara: Aydın Kitabevi Yayınları.

Evliya Çelebi (1318). Evliya Çelebi Seyahatnamesi. C.7. İstanbul: İkdam Matbaasi.

Gürkan, E. S. (2015). "Bir Diplomasi Merkezi Olarak Yeni Çağ İstanbul'u”. (Çev. Öykü Özer-Ahmet Özer). Antik Çağ'dan 21. Yüzyıla Büyük İstanbul Tarihi Cilt II., Coşkun Y1lmaz (Ed.). İstanbul: İstanbul Büyükşehir Belediyesi Yayınları. Ss. 372-399.

Kütükoğlu, M. S. (1989). "XVIII. Yüzyılda Osmanlı Devletinde Fevkalâde Elçilerin Ağırlanması", Türk Kültürü Araştırmaları Prof. Dr. İsmail Ercüment Kuran'a Armağan, Y1l: XXVII/ 1-2, Ss. 199-231.

Mustafa Nuri Paşa. (1992). Netayic ül-Vukuat Kurumları ve Örgütleriyle Osmanlı Tarihi C: III-IV, (Sad. Neşet Çağatay). Ankara: Türk Tarih Kurumu Basimevi.

Nicolson, H. (2001). The Evolution of Diplomatic Method. Leicester: University of Leicester,

Pakalın, M. Z. (1983). Osmanlı Tarih Deyimleri ve Terimleri Sözlüğü 2. 2. Bask1. İstanbul: MEB Basımevi.

Şemseddin Sami. (1317). Kamûs-ı Türkî. İstanbul: İkdam Matbaas1.

Topaktaş, H. (2014). Osmanll-Lehistan Diplomatik ilişkileri Francizsek Piotr Potocki'nin Istanbul Elçiliği (1788-1793). Ankara: Türk Tarih Kurumu.

Topaktaş, H. (2015). "Osmanlı Diplomasisinde "Tayinat" Sisteminin Uygulanış1 ve Kaldırılış1 (1794) Üzerine Bazı Tespitler". Akademik Incelemeler Dergisi. S 10 (1). Ss. 31-49.

Turan, Ş. (1964). “1560 Tarihinde Anadolu'da Yiyecek Maddeleri Fiyatlarını Gösteren Bir İran Elçilik Hey'eti Masraf Defteri”. AÜDTCF Dergisi. S. 22 (3-4). Ss. 273-294.

Uzunçarş1l1, İ. H. (1988). Osmanlı Devleti'nin Merkez ve Bahriye Teşkilatı. 3. Baskı. Ankara: TTK Basımevi.

Uzunçarşılı, İ. H. (1995). Osmanlı Tarihi. C. 5. 6. Baskı. Ankara: TTK Basımevi. 


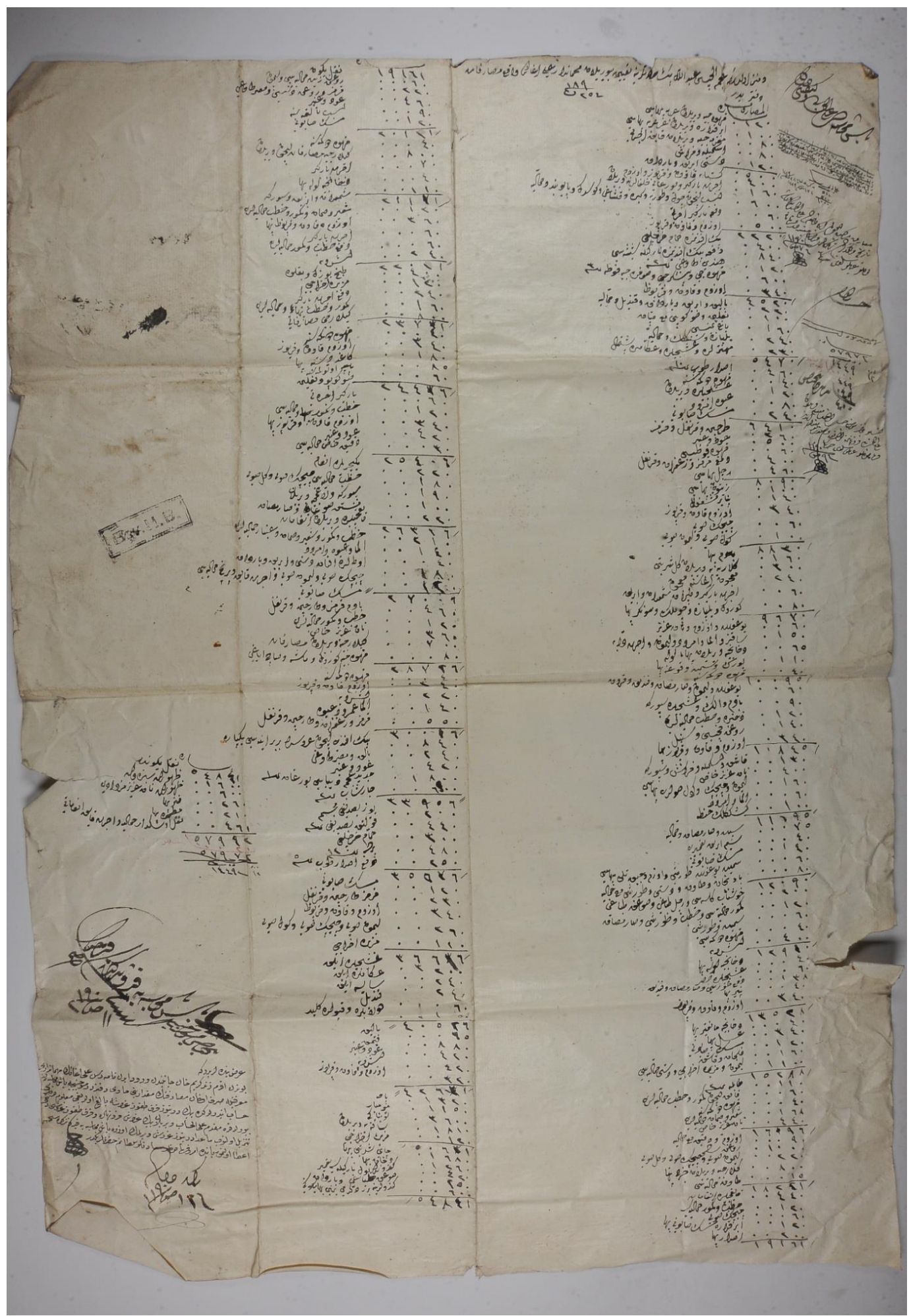

EK: BOA. C. HR. 184/9154. 